\title{
Kadar Antibodi Anti-dsDNA dan Urine Monocyte Chemoattractant Protein-1 pada Nefritis Lupus
}

\section{Levels of anti-dsDNA Antibodies and Urin Monocyte Chemoattractant Protein-1 in Lupus Nephritis}

\author{
Hani Susianti ${ }^{1}$, Yuliana Salman ${ }^{2}$, Atma Gunawan ${ }^{3}$, Kusworini Handono ${ }^{1}$ \\ ${ }^{1}$ Laboratorium Patologi Klinik Rumah Sakit Umum Dr. Saiful Anwar Malang \\ ${ }^{2}$ Sekolah Tinggi Ilmu Kesehatan Husada Borneo Banjarbaru \\ ${ }^{3}$ Laboratorium Ilmu Penyakit Dalam Rumah Sakit Umum Dr. Saiful Anwar Malang
}

\begin{abstract}
ABSTRAK
Lupus eritematosus sistemik (LES) merupakan penyakit autoimun yang ditandai oleh peradangan kronis dan akut. Biomarker klasik untuk mendeteksi adanya penyakit LES adalah antibody anti-double stranded DNA (anti-dsDNA) dan urine Monocyte Chemoattractant Protein-1 (uMCP-1). Penelitian ini dilakukan untuk mengkaji hubungan antara kedua biomarker tersebut dengan klasifikasi histopatologis nefritis lupus untuk mengganti biopsi ginjal dalam penentuan kelas histopatologi nefritis lupus. Penelitian ini dilakukan selama 11 bulan berupa studi observasional dengan pengambilan sampel darah dan urin untuk mengetahui kadar antibodi anti-dsDNA dan MCP-1, serta biopsi ginjal untuk menentukan kelas nefritis lupus berdasarkan klasifikasi WHO tahun 1982. Data hasil penelitian menunjukkan tidak ada perbedaan yang signifikan $(p=0,208>\alpha)$ antara mean rank kadar anti-dsDNA pada kelompok kontrol dan kelompok kasus, begitu pula dengan hasil perbandingan mean rank kadar uMCP-1 ( $p=0,247>\alpha)$. Uji korelasi Spearman's rho, menunjukkan hubungan signifikan kadar anti-dsDNA dan kadar uMCP-1 $(r=0,861 ; p<0,001)$. Dapat disimpulkan bahwa tidak terdapat perbedaan kadar biomarker antibodi anti-dsDNA dan urine MCP1 pada kejadian nefritis lupus dan klasifikasi histopatologi nefritis lupus, namun terdapat hubungan yang sangat erat antara kadar biomarker antibodi anti-dsDNA dengan kadar urine MCP1. Nilai sensitifitas kadar anti-dsDNA dan UMCP-1 lebih rendah yaitu $20 \%-40 \%$ dibandingkan dengan nilai spesifisitasnya, yaitu $50 \%-83,33 \%$.
\end{abstract}

Kata Kunci: Anti-dsDNA, uMCP-1, klasifikasi histopatologi, nefritis lupus

\begin{abstract}
Systemic lupus erythematosus (SLE) is an autoimmune disease characterized by chronic and acute inflammation. The most common serious complications of SLE is lupus nephritis. Biomarkers that showed high specificity for SLE especially in lupus nephritis is antibodies anti-double stranded DNA (anti-dsDNA) and monocyte chemoattractant protein urine-1 (UMCP-1). This study was aimed to determine the correlation between UMCP-1 and anti ds-DNA antibodies with nephritis with histopathological classification of lupus nephritis. An cross sectional study was performed 11-month with blood and urine sampling to determine levels of anti-dsDNA antibodies and MCP-1 in patients with SLE, and renal biopsy to determine the class of lupus nephritis according to WHO (1982) classification. The results showed no significant difference $(p=0,208)$ between mean rank anti-dsDNA levels of control and cases group. Similarly, the comparison of mean rank levels of urinary UMCP-1. The Kruskal-Wallis test demonstrated the comparison of anti-dsDNA levels among 3 groups have no significant difference $(p=0,187)$, likewise the mean rank in urine MCP-1 levels among 3 groups $(p=0,197)$. The Spearman's rho correlation test, the results obtained a strong and significant correlation between the levels of anti-dsDNA and urine levels of MCP-1 $r=0,861 ; p=0,000)$. It can be concluded that the levels of anti-dsDNA antibody biomarkers and urinary MCP1 was not associated with incidence and histopathological classification of lupus nephritis, but there is a strong correlation between anti-dsDNA antibodies and UMCP-1 levels and the sensitivity levels of anti-dsDNA and uMCP-1 was lower (20\%$40 \%$ ) than the specificity (50\%-83,33\%).
\end{abstract}

Keywords : Anti-dsDNA, histopathology class, lupus nephritis, uMCP-1

Jurnal Kedokteran Brawijaya, Vol. 27, No. 2, Agustus 2012; Korespondensi: Hani Susianti. Laboratorium Patologi Klinik Rumah Sakit Umum Dr. Saiful Anwar Malang, Jl. Jaksa Agung Suprapto No. 2 Malang Tel. (0341) 366242 Email: hanisusianti@yahoo.com 


\section{PENDAHULUAN}

Lupus Eritematosus Sistemik (LES) adalah penyakit autoimun yang ditandai oleh peradangan kronis dan akut pada berbagai jaringan tubuh seperti ginjal, hati, sendi, sel darah merah, leukosit dan trombosit. Berdasarkan Sudoyo (2007), data dari Yayasan Lupus Indonesia, penderita LES diperkirakan mencapai 5 juta orang di seluruh dunia (1). Komplikasi yang sering terjadi pada LES dan sering menimbulkan akibat yang serius adalah nefritis lupus. Perkiraan prevalensi keterlibatan ginjal secara klinis pada pasien LES berkisar antara 30\%-90\%. Nefritis lupus lebih sering dijumpai pada wanita dengan rasio prevalensi LES wanita:pria sebesar 9:1 (2,3).

Adanya pembentukan imun kompleks antara autoantibodi dan target antigen (self-antigen) pada LES akan memicu pelepasan mediator proinflamasi seperti MCP-1 akan merekrut monosit atau makrofag dan sel efektor imun lainnya yang akan menyebabkan kerusakan jaringan $(4,5)$. Kemampuan untuk mengetahui komplikasi nefritis lupus pada pasien LES sebelum nampak adanya gangguan organ sangat diperlukan. Oleh karena itu, diperlukan suatu biomarker yang dapat menggambarkan aktivitas penyakit. Biomarker klasik untuk mendeteksi adanya penyakit LES adalah antibody anti-double stranded DNA (anti-dsDNA). Anti dsDNA merupakan suatu pemeriksaan klasik yang akan menunjukan spesifitas cukup tinggi untuk LES khususnya pada penderita nefritis lupus (6). Berbagai bukti klinis, biopsi ginjal dan studi hewan coba, menyarankan bahwa antibodi anti-dsDNA merupakan autoantibodi utama yang terlibat dalam patogenesis nefritis lupus, bahwa aviditas tinggi dari antibodi anti-dsDNA sangat terkait dengan patogenisitas $(7,8)$.

Biomarker lain yang dapat menggambarkan aktivitas penyakit LES khususnya nefritis lupus adalah urine Monocyte Chemoattractant Protein-1 (uMCP-1). Monocyte chemoattractant protein-1 (MCP-1) adalah polipeptida monomerik yang memegang peranan penting dalam infiltrasi leukosit ke dalam ginjal meningkatkan perlekatan leukosit ke endotel serta meningkatkan permeabilitas endotel. MCP-1 juga dapat memediasi respon fibrogenik dan peningkatan kadarnya berhubungan dengan temuan histologis berupa jaringan parut pada biopsi ginjal (9-12). Peningkatan uMCP-1 berperan dalam terjadinya hiperseluler pada endokapiler glomerulus yang disebabkan karena infiltrasi leukosit, termasuk neutrofil, monosit dan limfosit serta adanya proliferasi endotelial glomerulus dan sel mesangial $(13,14)$.

Meskipun beberapa penelitian menunjukkan bahwa uMCP-1 dan antibodi anti ds-DNA sebagai biomarker yang menjanjikan pada nefritis lupus, namun masih terdapat kontroversi dengan penelitian yang lain. Di Indonesia belum ada penelitian yang dilakukan untuk melihat perbedaan kadar antara kedua biomarker tersebut yang dihubungkan dengan klasifikasi histopatologis nefritis lupus. Kombinasi dari beberapa biomarker akan membantu memperkirakan aktivitas penyakit dan gambaran (klasifikasi) histopatologi ginjal. Pendekatan ini diharapkan dapat mengganti biopsi ginjal dalam penentuan kelas histopatologi nefritis lupus karena hal tersebut sangat diperlukan dalam penangangan yang tepat dari pasien nefritis lupus, meningkatkan efesiensi terapi sehingga mengurangi efek toksisitas terapi.

\section{METODE}

Penelitian ini merupakan studi observasional yang dilakukan secara cross-sectional study selama 11 bulan. Pemeriksaan dilakukan dengan pengambilan sampel darah dan urin untuk mengetahui kadar antibodi antidsDNA dan MCP-1 pada pasien lupus, serta dilakukan biopsi ginjal untuk menentukan kelas nefritis lupus berdasarkan klasifikasi WHO. Variabel yang diukur adalah kadar urine MCP-1 dan antibodi anti-dsDNA dengan outcome klasifikasi histopatologi nefritis lupus

Pemeriksaan antibodi anti-dsDNA dilakukan dengan dengan metode metoda ELISA-Indirect menggunakan ELISA Kit. Antigen dsDNA sintetik yang telah dilekatkan pada sumur ditambahkan serum penderita yang telah diencerkan sebanyak 100x, selanjutnya dinkubasi selama 30 menit. Berikutnya dilakukan pencucian untuk membuang antigen-antigen yang tidak terikat. Ditambahkan enzyme conjugate (Goat anti-human IgG antibody conjugated with HRP) dan di inkubasi kembali selama 30 menit. Setelah dilakukan inkubasi dan pencucian, ditambahkan Tetramethyl benzidine (TMB) subrate solution dan diinkubasi kembali selama 15 menit. Tahap selanjutnya adalah penambahan stop solution dan perubahan warna yang terjadi diukur dengan spektrofotometer dengan panjang gelombang $450 \mathrm{~nm}$.

Pemeriksaan urine MCP-1 dilakukan dengan metode ELISA menggunakan RayBio ELISA Kit. Sampel urin yang diperoleh, disimpan dalam $-80^{\circ} \mathrm{C}$ sampai cukup jumlahnya untuk diperiksa. Pada sumur mikrotiter yang telah dilapisi antibodi anti-human MCP-1 ditambahkan sampel urin $100 \mu l$. Inkubasi selama 3 jam pada suhu ruang, tambahkan antibodi biotin dan inkubasi kembali selama 1 jam. Tambahkan Streptavidin solution (inkubasi selama 45 menit). Tambahkan Tetramethyl benzidine (TMB) solution dan inkubasi selama 1 jam, reaksi dihentikan dengan penambahan stop solution, kemudian dibaca dengan spektrofotometer pada $450 \mathrm{~nm}$.

Biopsi ginjal dilakukan oleh dokter Ahli Penyakit Dalam konsultan Ginjal Hipertensi di seksi Ginjal-Hipertensi Laboratorium Ilmu Penyakit Dalam RSSA dengan tuntunan Ultrasonografi (USG-Guided). Pengambilan jaringan dilakukan sebanyak 2 kali. Jaringan pertama diawetkan dalam formalin $10 \%$, sedangkan yang kedua dengan OCT compound. Jaringan ginjal yang diperoleh segera dikirim ke Laboratorium Patologi Anatomi Fakultas Kedokteran Universitas Brawijaya Malang.

Pembuatan preparat histologi untuk pemeriksaan kelas histopatologis nefritis lupus diawali dengan pemotongan jaringan. Jaringan dipilih yang terbaik sesuai dengan yang akan diteliti. Jaringan dipotong dengan ketebalan 2-3 mm. Jaringan yang telah dipotong dimasukkan kasaset sesuai kode gross. Kemudian di masukkan ke dalam larutan formalin $10 \%$ fiksasi dan diproses menggunakan alat Tissue Tex Processor. Jaringan diangkat dari mesin Tissue Tex Processor, kemudian jaringan diblok dengan paraffin sesuai kode jaringan dan kemudian dipotong menggunakan mesin microtome dengan ketebalan 3-5 $\mu \mathrm{m}$. Jaringan yang telah dipotong sesuai dengan ketebalan, dimasukkan ke dalam oven selama 15 menit pada suhu $70^{\circ} \mathrm{C}$, kemudian masukkan ke dalam larutan xylol selama 15 menit. Selanjutnya masing-masing jaringan dicelupkan ke dalam alkohol $96 \%$ sebanyak 4 kali 
selama 3 menit, dicuci dengan air mengalir selama 10 menit dan diberikan pewarnaan dengan cat utama Haris Haematoxilyn, lalu direndam selama 15 menit. Selanjutnya dilakukan pencucian dengan air mengalir dan dicelupkan ke dalam alkohol asam $1 \%$ dilanjutkan dengan ammonia air. Proses berikutnya dilakukan dehidrasi dengan memasukkan preparat/jaringan ke dalam alkohol $80 \%$ dan $96 \%$ selama 3 menit, kemudian dilakukan penjernihan dengan memasukkan ke dalam larutan xylol selama 15 menit untuk kemudian dilakukan mounting dengan entelan dan deck glass. Pemeriksaan kelas histopatologi ginjal dilakukan oleh dokter spesialis Patologi Anatomi di bagian Patologi Anatomi FKUB dengan menggunakan mikroskop cahaya. Klasifikasi kelas histopatologi NL ditetapkan berdasarkan kriteria WHO tahun 1982.

Data kuantitatif berupa kadar antibodi anti-dsDNA dan urine MCP-1 akan di analisa dengan bantuan program SPSS versi 19. Uji statistik yang digunakan adalah statistik non parametrik, yaitu uji Mann-Whitney, uji KruskalWallis dan uji korelasi Spearman rho dengan taraf signifikansi $p \leq 0,05$ serta uji diagnostik. Data kualitatif berupa gambaran histopatologis dari nefritis lupus untuk menetapkan kelas nefritis lupus berdasarkan klasifikasi WHO tahun 1982 (15).

\section{HASIL}

\section{Karakteristik Subjek Penelitian}

Penelitian ini menggunakan 31 sampel pasien biopsi yang terdiri atas 6 pasien LES tanpa nefritis lupus (kontrol) dan 25 pasien LES dengan nefritis lupus. Pasien dalam penelitian ini hampir semua perempuan, dengan usia terbanyak 21-30 tahun, semua dari Jawa dan sudah lebih dari 2 tahun $(51,6 \%)$ menderita sakit. Gejala klinis yang paling banyak muncul adalah sindroma nefritis $(80,64 \%)$ dengan gambaran nyeri sendi $(54,8 \%)$ dan rash $(41,9 \%)$

Tabel 1. Karakteristik subjek penelitian.

\begin{tabular}{lc}
\hline Karakteristik & Prosentase \\
\hline Jenis & \\
Laki-laki & $6.45 \%$ \\
Perempuan & $93.55 \%$ \\
Usia (tahun) & \\
$10-20$ & $29.03 \%$ \\
$21-30$ & $48.38 \%$ \\
$31-40$ & $38.71 \%$ \\
Suku & \\
Jawa & $100 \%$ \\
Lama Sakit & \\
$<1$ tahun & $16.13 \%$ \\
$1-2$ tahun & $32.26 \%$ \\
$>2$ tahun & $51.61 \%$ \\
Gejala Klinis & \\
Nefritis & $80.64 \%$ \\
Odema & $29.03 \%$ \\
Nyeri sendi & $54.83 \%$ \\
Rash & $41.93 \%$ \\
Seroritis & $9.68 \%$ \\
Silent lupus nephriti & $25.80 \%$ \\
\hline
\end{tabular}

Pada penelitian ini, telah diamati gambaran histopatologi ginjal dan diukur kadar antibodi anti-dsDNA dan kadar urin MCP-1 yang diambil dari 31 pasien LES yang telah dibiopsi untuk menentukan kelas nefritis lupus. Hasil gambaran klasifikasi histpatologi ginjal dari pasien LES menurut WHO tahun 1982 disajikan pada Gambar 1.
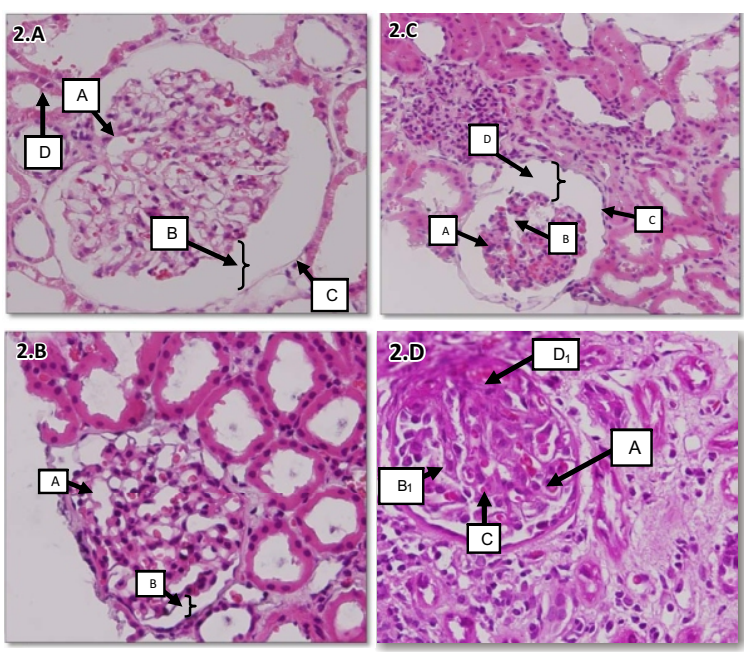

Gambar 1. Gambar histapatologi ginjal pasien LES menurut klasifikasi WHO 1982 (pembesaran 400x)

Keterangan:

A. Gambaran histopatologi kelas I (kontrol).

Tampak jaringan biopsi ginjal yang pada umumnya normoseluler. (A). Lumen pembuluh kapiler paten, dinding pembuluh kapiler tidak menebal. (B). Ruang bowman tidak menyempit. (C) Kapsula Bowman tidak menebal. (D). Tubulus tidak atrofik, interstitium tidak fibrotik, tidak terdapat infiltrasi sel radang. Pembuluh darah tidak menunjukkan kelainan (AG4).

B. Gambaran histopatologi kelas II (kontrol).

Tampak jaringan biopsi kebanyakan normoseluler dengan penambahan matriks dan sel mesangial. Tidak didapatkan infiltrasi sel-sel neutrofil pada glomerulus. (A). Lumen kapiler paten, tidak didapatkan penebalan dinding kapiler maupun gambaran wire loop. Tidak didapatkan nekrosis fibrinoid dan karyorrheksis. (B). Ruang bowman tidak menyempit dan tidak didapatkan kresent (AG 34).

C. Gambaran histopatologi kelas III.

(A). Tampak jaringan ginjal hiperseluler dengan proliferasi endokapiler ringan dengan penambahan sel-sel mesangial. Tidak didapatkan infiltrasi sel-sel neutrofil pada glomerulus. (B) Lumen kapiler paten, dinding kapiler menebal dan tidak tampak gambaran wire loop. Tidak didapatkan nekrosis fibrinoid dan karyorrheksis. (C). Simpai bowman tidak menebal, (D) ruang bowman tidak menyempit dan tidak didapatkan kresent (AG 27).

D. Gambaran histopatologi kelas V.

(A). Tampak jaringan biopsi ginjal hiperseluler dengan proliferasi endokapiler ringan disertai dengan penambahan matriks dan sel mesangial. (B). Didapatkan beberapa sel neutrofil pada 1-2 glomerulus. (C). Lumen kapiler paten, sebagian menyempit serta didapatkan penebalan dinding kapiler tanpa terlihat gambaran wire loop. Tidak didapatkan nekrosis fibrinoid maupun karyorrheksis. (D) Simpai bowman tidak menebal, ruang bowman sebagian menyempit, didapatkan kresent fibroseluler pada 2 buah glomeruli (AG 1).

Karakteristik sebaran data kadar anti-dsDNA dan kadar uMCP-1 dari subjek penelitian diukur menggunakan 
metode ELISA dan diklasifikasikan berdasarkan klasifikasi histopatologi nefritis lupus menurut WHO tahun 1982.

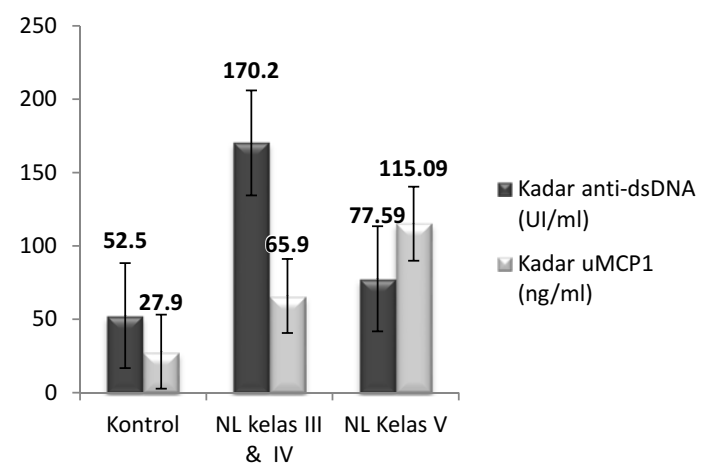

Gambar 2. Kadar anti dsDNA dan uMCP1 menurut klasifikasi histopatologis WHO.

Gambar 2 menunjukkan nilai rerata kadar anti-dsDNA dan kadar uMCP-1 dari subyek penelitian yang terbagi dalam masing-masing kelompok (derajat kelainan histopatologis) menurut klasifikasi WHO. Nilai rerata kadar anti-dsDNA pada kelompok kontrol sebesar 52,5 $\mathrm{UI} / \mathrm{ml}$, kelas III dan IV sebesar 170,2 UI/ml dan kelas V sebesar 77,59 Ul/ml. Nilai rerata kadar UMCP1 pada kelompok kontrol paling rendah $(27,9 \mathrm{ng} / \mathrm{ml})$, dan semakin besar dengan meningkatnya derajat kelainan histopatologis yaitu kelas III dan IV sebesar 65,9 ng/ml dan kelas V sebesar 115,09 $\mathrm{ng} / \mathrm{ml}$.

\section{Uji Perbandingan Kelompok Kontrol dan Kasus}

Untuk membuktikan hipotesis penelitian yang pertama, maka digunakan uji Mann-Whitney digunakan untuk membandingkan kelompok kontrol $(n=6)$ dan kelompok kasus (nefritis lupus) $(n=25)$. Tampak pada Tabel 2 pada hasil uji Mann-Whitney menunjukkan tidak ada perbedaan yang bermakna $(p=0,208)$ perbandingan kedua rerata rank kadar anti-dsDNA, dengan nilai rerata rank kelompok kontrol 11 dan kelompok kasus 17,02. Hal ini dapat diartikan bahwa tingginya kadar biomarker antibodi anti-dsDNA belum tentu menunjukkan kejadian nefritis lupus. Demikian pula hasil perbandingan rerata rank kadar urine MCP-1 kelompok kontrol sebesar 12 dan kelompok kasus sebesar 19.96 menunjukkan tidak ada perbedaan yang bermakna $(p=0,247)$. Hal ini dapat diartikan bahwa tingginya kadar urine MCP-1 belum tentu menunjukkan kejadian nefritis lupus.

Tabel 2. Perbandingan kontrol dan kasus

\begin{tabular}{lccc}
\hline \multirow{2}{*}{ Variabel } & Kontrol $(\mathrm{n}=6)$ & Kasus $(\mathrm{n}=25)$ & \multirow{2}{*}{ p-value } \\
\cline { 2 - 3 } & Rerata Rank & Rerata Rank & \\
\hline anti-dsDNA & 11 & 17,02 & 0,208 \\
uMCP-1 & 12,00 & 16,96 & 0,247 \\
\hline
\end{tabular}

Keterangan: $p$-value $>0,05$ tidak ada perbedaan yang bermakna, $p$-value $<0.05$ ada perbedaan yang bermakna

Tampak pada Tabel 3 pada hasil uji perbandingan ketiga rerata rank kadar anti-dsDNA menunjukkan tidak ada perbedaan yang bermakna $(p=0,187)$, dengan nilai rerata rank masing-masing kelompok sebesar 11,75, 18,81 dan 13,83. Masih pada Tabel 3 pada hasil uji perbandingan ketiga mean rank kadar urine MCP-1 menunjukkan tidak ada perbedaan yang bermakna $(p=0,197>\alpha)$, dengan nilai rerata rank masing-masing kelompok sebesar 12, 15,13 dan 20,22. Hal ini berarti bahwa kadar anti-dsDNA dan urine MCP-1 antar klasifikasi histopatologi pasien nefritis lupus tidak menunjukkan perbedaan yang bermakna.

Tabel 3. Perbandingan keempat kelompok sampe

\begin{tabular}{crcc}
\hline Kelompok & $\mathrm{n}$ & $\begin{array}{c}\text { Rerata rank anti- } \\
\text { dsDNA (UI/ml) }\end{array}$ & $\begin{array}{c}\text { Rerata rank urine } \\
\text { MCP-1 (ng/ml) }\end{array}$ \\
\hline kontrol & 6 & 11,75 & 12,00 \\
Klas III \& IV & 16 & 18,81 & 15,13 \\
Klas V & 9 & 13,83 & 20,22 \\
\hline$p$-value & & 0,187 & 0,197 \\
\hline
\end{tabular}

Untuk membuktikan hipotesis penelitian yang ketiga, maka digunakan uji korelasi Spearman's rho yang menunjukkan bahwa ada korelasi yang bermakna signifikan dan kuat antara kadar anti-dsDNA dan kadar urine MCP-1 ( $p=0,000 ; r=0,861)$.

Pada Tabel 4 menunjukkan hasil uji diagnostik antara kadar anti-dsDNA dan kadar UMCP-1, didapatkan nilai sensitifitas $20 \%$, spesifisitas $83,33 \%$, nilai ramal positif $83,33 \%$ dan nilai ramal negatif $20 \%$.

Tabel 4. Uji diagnostik kadar anti-dsDNA dan kadar uMCP-1

\begin{tabular}{cccc}
\hline $\begin{array}{c}\text { Kadar anti-dsDNA } \\
\text { (Ul/ml) dan }\end{array}$ & \multicolumn{2}{c}{ Biopsi ginjal } & \\
\cline { 2 - 3 } Kadar uMCP-1 $(\mathrm{pg} / \mathrm{ml})$ & Positif & Negatif & \\
\hline Positif & 5 & 1 & 6 \\
Negatif & 20 & 5 & 25 \\
Jumlah & 25 & 6 & 31 \\
\hline
\end{tabular}

\section{DISKUSI}

Lupus eritematosus sistemik merupakan prototype dari kelainan autoimun yang mempunyai karakteristik keterlibatan berbagai multisistem dan adanya autoantibodi (antara lain anti- dsDNA) yang secara langsung menyerang komponen sel. Pada penelitian ini, menggunakan 31 sampel pasien SLE yang terdiri atas 25 pasien dengan nefritis lupus dan 6 pasien SLE non nefritis lupus. Pada penelitian ini jenis kelamin pasien 93,55\% perempuan, hal ini sesuai dengan penelitian yang dilaporkan oleh Rus (2007) yang menyatakan bahwa rasio prevalensi LES antara wanita dan pria sebesar 9:1. Gambaran usia subjek penelitian menunjukkan rentang usia yang paling banyak berkisar antara 21-30 tahun sebesar $48,38 \%$, hal ini sesuai dengan penelitian yang menyatakan bahwa sebagian besar pasien berkembang menjadi lupus nefritis pada awal penyakitnya $(14,16)$.

Hasil penelitian menunjukkan kadar anti-dsDNA paling tinggi pada nefritis lupus kelas III dan IV sebesar 170,2 $\mathrm{UI} / \mathrm{ml}$ dan urine MCP-1 paling tinggi pada kelas $\mathrm{V}$ sebesar 
$115,09 \mathrm{ng} / \mathrm{ml}$. Meskipun demikian data tersebut tidak dapat digunakan sebagai perbandingan untuk menguji tingkat signifikansi antar kelompok, karena sebaran data tidak normal dan jumlah data tiap kelompok tidak sama besar. Beberapa alasan yang menyebabkan jumlah data tiap kelompok tidak sama besar, terutama pada kelompok kontrol adalah keterbatasan didapatkannya jumlah sampel penelitian dan adanya silent lupus nephritis, yaitu suatu keadaan dimana hasil pemeriksaan laboratorium sebagai penunjang penegakkan diagnosis menunjukkan hasil yang negatif, namun hasil biopsi memperlihatkan gambaran nefritis lupus (14).

Berdasarkan hasil biopsi diperoleh gambaran Kelas I dan II , yaitu jaringan ginjal yang pada umumnya normoseluler, Lumen pembuluh kapiler paten, dinding pembuluh kapiler tidak menebal, ruang Bowman tidak menyempit dan tubulus tidak atrofik. Pada kelas II terdapat penambahan ringan matriks dan atau sel mesangial. Hal ini sesuai dengan gambaran klasifikasi WHO tahun 1982 (14). Selain itu juga diperoleh gambaran histopatologi kelas III dan IV. Dari gambaran tersebut, diperoleh karakteristik jaringan ginjal yang hiperseluler dengan proliferasi endokapiler ringan dengan penambahan selsel mesangial, Kelas III digambarkan memiliki kerusakan atau glomerulus lesions $<50 \%$ dari total glomerulus, sedangkan kelas IV digambarkan memiliki kerusakan atau glomerulus lesions $>50 \%$ dari total glomerulus. Hal ini sesuai dengan gambaran klasifikasi WHO tahun 1982 yang menyatakan bahwa sebagian besar kasus dari kelas III dan kelas IV nefritis lupus endocapillary mengalami hiperseluleritas. Kelas III nefritis didefinisikan sebagai focal segmental atau global endocapillary dan extracapillary glomerulonephritis kurang dari $50 \%$ dari total glomerulus. Kelas IV didefinisikan sebagai diffuse segmental atau global endocapillary dan extracapillary glomerulonephritis lebih dari 50\% dari total glomerulus. Pada penelitian ini juga diperoleh gambaran klasifikasi kelas $\mathrm{V}$ yang sesuai dengan klasifikasi WHO tahun 1982 yaitu pada kelas $\mathrm{V}$ terdapat penebalan dinding kapiler karena adanya deposit kompleks imun disepanjang kapiler glomerular (13).

Berdasarkan hasil analisis terhadap kadar anti dsDNA yang diambil dari sampel serum, terlihat bahwa tidak ada perbedaan yang signifikan antara kelompok kontrol dan kelompok nefritis lupus. Begitu pula halnya pada perbandingan kadar anti dsDNA antar kelas nefritis lupus . Beberapa alasan yang dapat menjelaskan hasil di atas, yang pertama penelitian yang dilakukan oleh Mortensen \& Rekvig (2009) yang menyatakan bahwa masih diragukan tentang peranan imun kompleks antibodi DNA-anti DNA yang meningkat akan menyebabkan lupus nefritis, karena tidak semua pasien dengan antibodi anti-DNA berkembang menjadi lupus nefritis (17). Alasan kedua, yaitu pada Amoura (1999) menyatakan bahwa penelitian pada nefritis lupus menunjukkan bahwa DNA bebas tidak terdapat dalam sirkulasi dan sirkulasi kompleks DNA dan anti-DNA sangat sulit untuk diidentifikasi (18). Selain itu, penelitian pada hewan coba juga menunjukkan bahwa injeksi intravenous dari kompleks DNA dan anti-DNA gagal menunjukkan hasil lokalisasinya pada glomerulus, sehingga titer dari serum DNA tidak terdeteksi pada hewan coba tersebut (19). Alasan ketiga, yaitu adanya keragaman dari pengenalan antigen oleh antibodi DNA menandakan bahwa beberapa penelitian tidak dapat menentukan autoantigen yang mungkin hadir di mesangial sel (20). Studi terbaru menunjukkan bahwa antibodi anti-DNA merupakan suatu patogenik terhadap ginjal melalui cross-reactivity secara langsung atau melalui sebuah jembatan antigen nuclear yang berikatan dengan sel glomerulus (21).

Selain mengukur kadar anti dsDNA, pada penelitian ini juga diukur kadar urine MCP-1. Berdasarkan hasil analisis kadar urine MCP-1, menunjukkan bahwa tidak ada perbedaan yang signifikan antara kelompok kontrol dan kelompok nefrits lupus. Begitu pula perbandingan antar kelas pada nefritis lupus, tidak ada perbedaan yang signifikan. Polimorfisme gen UMCP-1 dapat mempengaruhi kadar MCP-1 dan dapat menjadi faktor pemicu terjadinya nefritis lupus $(4,22)$. Pada penelitian yang dilakukan oleh Tian et.al (2007) menyatakan bahwa uMCP-1 tidak berhubungan dengan histopatologis indeks aktivitas penyakit dan peningkatan uMCP-1 bukan merupakan prediktor independen dari kerusakan ginjal. Pada penelitian tersebut, yang menjadi prediktor independen adalah urine RANTES dan M-CSF. Untuk menentukan klasifikasi kelas nefritis lupus diperlukan penambahan parameter atau biomarker lain seperti RANTES dan M-CSF (23).

Hipotesis ketiga dari penelitian ini, akan dibuktikan hubungan. Berdasarkan hasil analisa data, diperoleh hubungan yang sangat kuat dan signifikan antara kadar anti-dsDNA dan urine MCP-1. Hal ini sesuai dengan patogenesis bahwa peningkatan uMCP-1 berkaitan dengan adanya deposit kompleks imun yang salah satunya adalah autoantibodi anti-dsDNA. Deposit kompleks imun akan mencetuskan respon inflamasi karena aktivasi dari monosit/makrofag yang mengawali sebuah kaskade sitokin dan kemokin proinflamasi sehingga menyebabkan peningkatan kemokin MCP-1 $(14,24)$.

Pada uji diagnostik gabungan antara kadar anti-dsDNA dan uMCP-1, menunjukkan nilai sensitivitas yang rendah, yaitu $20 \%$. Hal itu menunjukkan bahwa pemeriksaan kadar antidsDNA dan UMCP-1 kurang sensitif untuk menentukan subyek yang mengalami nefritis lupus namun mempunyai nilai spesifisitas yang tinggi (83,33\%). Hal ini menunjukkan bahwa gabungan pemeriksaan kadar anti-dsDNA dan uMCP-1 spesifik untuk menentukan subjek yang bukan nefritis lupus jika hasil pemeriksaannya menunjukkan hasil yang negatif. Adapun nilai ramal positif sebesar 83,33\% dan nilai ramal negatif sebesar $20 \%$. Nilai ramal positif menunjukkan besarnya peluang subjek mengalami nefritis lupus jika kadar anti-dsDNA >60 UI/ml dan kadar uMCP-1 $>43,94 \mathrm{pg} / \mathrm{ml}$, sedangkan nilai ramal negatif menunjukkan besarnya peluang subyek tidak mengalami nefritis lupus jika kadar anti-dsDNA <60 UI/ml dan kadar uMCP-1 $<43,94$ $\mathrm{pg} / \mathrm{ml}$.

Faktor lain yang dapat mempengaruhi hasil penelitian ini, antara lain kondisi lingkungan, latar belakang pasien (adanya faktor genetik) dan riwayat penyakit sebelumnya serta lamanya waktu penggunaan obat-obatan yang bersifat imunosupresan yang berbeda-beda pada subyek penelitian. Semua faktor tersebut tidak dapat dikendalikan oleh peneliti mengingat keterbatasan sampel dan waktu penelitian. Hal ini merupakan keterbatasan dalam penelitian. 
Dapat disimpulkan bahwa kadar biomarker antibodi antidsDNA dan UMCP-1 tidak berhubungan dengan kejadian dan klasifikasi histopatologi dari nefritis lupus, namun terdapat hubungan yang sangat erat antara kadar

\section{DAFTAR PUSTAKA}

1. Bawazier LA, Dharmeizar, dan Markum HMS. Nefritis Lupus. Di dalam: Sudoyo WA (Ed). Buku Ajar IImu Penyakit Dalam edisi V. Jakarta: InternaPublishing; 2007.

2. Dooley MA. Clinical and Laboratory Features of Lupus Nephritis. In: Wallace DJ (Ed). Dubois' Lupus Erythematosus 7th edition. Philadelphia: Lippincott Williams \& Wilkins; 2007; p. 1112-1130.

3. Rus V, Maury EE, and Hochberg MC. Epidemiology of Systemic Lupus Erythematosus. In: Wallace DJ (Ed). Dubois' Lupus Erythematosus 7th edition. Philadelphia: Lippincott Williams \& Wilkins; 2007; p. 34-44.

4. Tucci M, Barnes EV, Sobel ES, et al. Strong Association of a Functional Polymorphism in the Monocyte Chemoattractant Protein 1 Promoter Gene with Lupus Nephritis. Arthritis and Rheumatism. 2004; 50(6): 1842-1849.

5. Li Y, Lee PY, Sobel ES, et al. Increased Expression of FcyRI/CD64 on Circulating Monocytes Parallels Ongoing Inflammation and Nephritis in Lupus. Arthritis Research \& Therapy. 2009; 11(1): R6.

6. Brent LH and Hamed FA. Lupus Nephritis. In: James K (Ed). Lupus Erythematosus 12th edition. Washington: Lippincott Williams \& Wilkins; 2008; p. 849-867.

7. Jaekell HP, Trabandt A, Grobe N, and Werle E. AntiDsdna Antibody Subtypes and Anti-C1q Antibodies: Toward a more Reliable Diagnosis and Monitoring of Systemic Lupus Erythematosus and Lupus Nephritis. Lupus. 2006; 15(6): 335-345.

8. Manson JJ, Ma A, Rogers $\mathrm{P}$, et al. Relationship between Anti-dsDNA, Anti-Nucleosome and AntiAlpha-Actinin Antibodies and Markers of Renal Disease Inpatients with Lupus Nephritis: A Prospective Longitudinal Study. Arthritis Research and Theraphy. 2009; 11(5): R154.

9. Marks SD, Williams SJ, Tullus K, and Sebire NJ. Glomerular Expression of Monocyte Chemoattractant Protein-1 is Predictive of Poor Renal Prognosis in Paediatric Lupus Nephritis. Nephrology Dialysis Transplantation. 2008; 23(11): 3521-3526.

10. Rovin BH, Song H, Birmingham DJ, Hebert LA, Yu CY, and Nagaraja HN. Urinary Chemokines as Biomarkers of Human Systemic Lupus Erythematosus Activity. Journal of the American Society of Nephrology. 2005; 16(2): 467-473.

11. Marks SD, Shah V, Pilkington C, and Tullus K. Urinary Monocyte Chemoattractant Protein-1 Correlates with Disease Activity in Lupus Nephritis. 2010; 25(11): 2283-2288. biomarker antibodi anti-dsDNA dengan kadar urine MCP1. Kombinasi kedua biomarker tersebut akan meningkatkan sensitifitas prediksi klasifikasi histopatologis nefritis lupus.

12. Mok CC. Biomarker for Lupus Nephritis: A Critical Apparaisal. Journal of Biomedicine and Biotechnology. 2010; 2010: 638413.

13. Lahita RG, Tsokos G, Buyon JP, and Koike T. Systemic Lupus Erythematosus. 4th edition. London: Academic Press; 2004.

14. Wallace DJ and Hahn BH. Dubois' Lupus Erythematosus. 4th edition. Philadelphia: Lippincott William \& Wilkins; 2007; p. 93-104.

15. Sastroasmoro S dan Ismael S. Dasar-dasar Metodelogi Penelitian Klinis. Edisi 2. Jakarta: Sagung Seto; 2002; hal. 137-141.

16. Seligman VA, Lum RF, Olson JL, Li H, and Criswell LA. Demographic Differences in the Outcome of SLE Nephritis: A Retrospective Analysis. American Journal of Medicine. 2002; 112(9): 726-729.

17. Mortensen ES and Rekvig OP. Nephritogenic Potential of Anti-DNA Antibodies against Necrotic Nucleosomes. Journal of the American Society of Nephrology. 2009; 20(4): 696-704.

18. Amoura Z, Koutouzov S, Chabre $\mathrm{H}$, et al. Presence of Antinucleosome Autoantibodies in a Restricted Set of Connective Tissue Diseases: Antinucleosome Antibodies of the lgg3 Subclass are Markers of Renal Pathogenicity in Systemic Lupus Erythematosus. Arthritis and Rheumatism. 2000; 43(1): 76-84.

19. Peutz-Koostra CJ, de Heer E, Hoedemaeker PJ, Abrass CK, and Bruijn JA. Lupus Nephritis: Lessons from Experimental Animal Models. Journal of Laboratory and Clinical Medicine. 2001; 137(4): 244-260.

20. Du Hui, Chen Min, Zhang Ying, Zhao Ming-hui, Wang Hai-Yan. Cross-Reaction of Anti-DNA Autoantibodies With Membrane Proteins of Human Glomerular Mesangial Cells in Sera from Patients with Lupus Nephritis. Clinical and Experimental Immunology. 2006; 145(1): 21-27.

21. Rekvig OP, Kalaaji M, and Nossent H. Anti-DNA Antibody Subpopulations and Lupus Nephritis. Autoimmunity Reviews. 2004; 3(2): 1-6.

22. Kim HL, Lee DS, Yang SH et al. The Polymorphism of Monocyte Chemoattractant Protein-1 is Associated with the Renal Disease of SLE. American Journal of Kidney Disease. 2002; 40(6): 1146-1152.

23. Tian S, Li J, Wang L, et al. Urinary Levels of RANTES and M-CSF are Predictor of Lupus Nephritis Flare. Inflammation Research. 2007; 56(7): 304-310.

24. Rahman A and Isenberg DA. Systemsic Lupus Erythematosus. The New England Journal of Medicine. 2008; 358(9): 929-939. 